\title{
The Review of Act Number 39 year 2004 Concerning The Placement and Protection for Indonesian Workers Abroad
}

\author{
H. Lalu. Husni ${ }^{1}$ \\ Faculty of law Mataram University \\ St. Majapahit No. 62 Mataram 83125, Phone. (0370), 633035, Fax. 626954 \\ Idrus Abdullah ${ }^{2}$ \\ Faculty of law Mataram University \\ St. Majapahit No. 62 Mataram 83125, Phone. (0370), 633035, Fax. 626954 \\ R.R.Cahyowati ${ }^{3}$ \\ Faculty of law Mataram University \\ St. Majapahit No. 62 Mataram 83125, Phone. (0370), 633035, Fax. 626954
}

\begin{abstract}
Labor migration in the era of free trade is a necessity, as part of the international community, Indonesia must participate in the globalization era, so it can not withstand nationals to seek a better life abroad. The purpose of this study to know and understand the weaknesses of the Act No. 39 of 2004 on the placement and protection of migrant workers, knowing and understanding the formulation of norms of protection of migrant workers to protect it properly. Research methods, normative law research, with the statute approach, conceptual approach, and conceptual approach. The types and sources of legal materials, using primary legal resourse, legal resourse secondary, and tertiary legal resource. Mechanical collection of legal materials, is done by performing a search, collection and documentation, processing and analysis of legal materials through a process of legal reasoning logical, systematic and coherent. Conclusion, weakness No..39 Act of 2004 regarding the Placement and Protection of Migrant Workers so it can not protect properly, this is due to provisions that prohibit or liability, but is not followed by the threat of legal sanction. Their norms do not provide clear who is the subject of law. Their formulation of norms "skill" that should be in the form of "necessity", so that the selection of a local recruit migrant workers can actually be done properly, and can prevent ekploitation human / human trafficking. The existence of norms regulating the legal subjects that are outside the boundaries of the Unitary Republic of Indonesia. Provisions that contradict each other (inconsistency). There are provisions governing unilateral legal subjects. Legal uncertainty because the agreements made on the basis of agreement between the workers / laborers (prospective TKI) with the employer / user services, the formulation of norms of protection of migrant workers to protect properly, namely by stating the principles of humanitarianism and the principle of national responsibility as the foundation footing.
\end{abstract}

Keywords: Placement, Protection, Indonesia Labor

\footnotetext{
${ }^{1}$ Lecturer in Faculty of Law of Mataram University

${ }^{2}$ Lecturer in Faculty of Law of Mataram University

${ }^{3}$ Lecturer in Faculty of Law of Mataram University
} 


\section{INTRODUCTION}

The history noted that migration between countries around Asia and particularly in the southeast Asia has been started since the colonization era. In the colonial period, most of international migration are forced migration and tend to be permanent. Most of the migrant were working as the contract coolie in the plantations owned by the foreign enterpreneur. International migration was linked with the colonial state (netherland) and the foreign enterpreneurs, not even push by the demand of the migrant, but more determined by the economic interest of the colonial state and foreign enterpreneur. The fate of the workers are very miserable because they are forced to work without protection under the law and worker condition. The enterpreneur was whipped them and treat them arbitrarily without humanity. ${ }^{4}$

The movement of the worker from one country to another is influenced by the development of economic, social, politic of the state. Therefore, the government should look into the migrant worker as the nature phenomenon as if the people urge to migrate from a village to the city or from a region to another to developed their welfare.

The high interest of indonesian workers (in short term known as TKI) to work abroad, in addition to the low employment opportunities of the resource country, also caused by the high difference in wage rates. Consequently, as long as the job opportunity are limited and wage differentials between Indonesia and other countries are conspicuous, the restriction of Indonesian workers to work abroad are less effective or in other words sending the workers abroad particularly unskilled worker has enough rational argumentation. ${ }^{5}$

Indonesia as the exporting country, known as the second largest in southeast asia after philippines. According to the 2010 data, the amount of indonesian worker (TKI) which work abroad are reach 6,5 million people. ${ }^{6}$ most of this migrant part are from remote area. Their departure abroad are pushed by their wish to seek out for job with the salary that can be use to developed family's welfare. According to the exist data, the palcement of worker is dominance by informal sector that reach $78 \%$. Around $60 \%$ from indonesian worker which working abroad is placed in the middle east such as Arab Saudi, Kuwait, Uni Emirat Arab, Jordania and Qatar. The rest of it is placed around Asia Pacific such as Malaysia, Singapore, Hongkong, South Korea and Taiwan, including United State.

\footnotetext{
4 Tajudin Noer Efendi Editor M.Arief Nasutioni, (1999), Peluang Kerja dan Antisipasi Menghadapi Era Pasar Bebas, Bandung : Alumni, p.39.

5 Lalu Husni, Prof.Dr.,SH,M.Hum, (2015), Hukum Penempatan Dan Perlindungan TKI (edisi revisi), Program Pascasarjana Universitas Brawijaya Malang, p.9.

6 Tribunnews. Com, tanggal 23 November $2010: 1$
} 
Although the migrant bring in a lot of foreign exchange value for the country and region as well ass participate to solve the worker problem of the state, they gain such a limited protection. ${ }^{7}$ This condition proved by many cases of violation of the migrant worker right in every year. The settelment dispute of the cases that the worker faces are yet optimal as they expected. This matter is not comparable with the contribution that they give, whether locally and nationally.

The presence of act No. 39 year 2014 is meant to created efficient placement mechanism which concerning the protection to avoid or at least reduce the problem which Indonesian worker faces. However, this act is have not yet able to give decent protection for indonesian worker. Various problem which Indonesian worker have to face abroad are started from pre placement, on the present and after its placement.

According to the fact it could arise some problem questions, namely: (1)what is the weakness of the act no.39 of 2014 on the placement and protection for indonesian workers so that it has not able to provide decent protection for indonesian workers?. (2) how is the norm formulation of the protection which is able to provide the decent protection for indonesian workers?

\section{METHOD}

Types of research: The normative legal research is a research that analysing law regulation in a coherent of legal order. ${ }^{8}$

approaching concept : As a normative-prescriptive legal reserach which concern about the law protection of Indonesian worker who is working abroad, various approach, namely, legal approach (statute approach) which are analysing and researching the rule of act that concerning the placement and protection for the indonesian worker as well as another regulation that related with the placement and protection for Indonesia worker. Secondly, a conceptual approach is to analyze the concept which related with the placement and legal protection for Indonesian worker who working abroad.

Types and resource of legal materials:

a) Primary legal resource is a binding legal materials which obtained from legislation that related to the placement and protection for indonesian worker who works abroad

\footnotetext{
7 Tita Naovalita dkk , (2006), " Perlindungan Sosial Buruh Migran Perempuan", Proseding Seminar, The World Bank bekerjasama dengan Kementerian Kesra RI, Jakarta 2-3 Mei 2006, p. 64.

8 Soetandyo Wignjosoebroto,(1995), "Sebuah Pengantar Ke Arah Perbincangan Tentang Pembinaan Penelitian HukumDalam PJP II”: Jakarta : BPHN Departemen Kehakiman, p. 5.
} 
b) Secondary legal resource is a legal resource which explained by the primary legal resource such as books, reserach result, scientific journals, article etc.

c) Tertiary legal resource is a legal resource which can deliver instruction nor explanation of primary and secondary legal resource such as law dictionary, enchyclopedy etc.

legal resource technique collection: The collection of legal resource is done by performed a research, collecting and studying documentation of primary, secondary and tertiary legal resource.

processing and analyzing of legal materials : The legal material collected further processed through the structuring phase, describe and systematyze of legal material and analyzing as a legal research, which is through the legal reasoning stage that is logic, systemic and coherent by abstracting laws and regulation which is linked with placement and protection for indonesian worker, while analyzing method of the legal material which is used in this research is a normative in the optic prescriptive ${ }^{9}$ by the reason of deductive-inductive in result of proposition or concept as an answer from the problems or a result/research finding.

\section{ANALYSIS AND DISCUSSION}

\section{The protection of indonesian workers by virtue of Act Number 39 year 2004}

The amount of indonesian worker abroad based on the research and development centre data (PUSLITFO BNP2TKI) $^{10}$

Table 1. the amount of indonesia worker abroad in periode of 2016 (january to november)

\begin{tabular}{|l|l|c|}
\hline No. & \multicolumn{1}{|c|}{ Region } & The amount of Indonesian workers \\
\hline 1. & Malaysia & 80.906 \\
\hline 2. & Taiwan & 70.379 \\
\hline 3. & Singapura & 15.037 \\
\hline
\end{tabular}

9 This method means to hermeneutically to find the rule of law which determine the obligation and juridical rights of the law subject in certain community situations which based and in the framework of the prevailing legal order which always referring to the positivism, coherency, justice and human dignity, which in its implementation ( able and always required to ) utilized the method and research product of social sciences. Next,, see part Bernard Arief Sidharta, (2000), Refleksi Tentang Struktur Ilmu Hukum Sebuah Penelitian tentang Fundasi Kefilsafatan dan Sifat Keilmuan Ilmu Hukum sebagai Landasan Pengembangan Ilmu Hukum Nasional, Bandung : Mandar Maju, p. 218.

${ }^{10}$ http://www.bnp2tki.go.id/uploads/data/data_09-122016_122020_Laporan_Pengolahan_Data_BNP2TKI_S.D_November_2016_pdf 


\begin{tabular}{|l|l|c|}
\hline 4. & Hongkong & 13.072 \\
\hline 5. & Saudi Arabia & 12.931 \\
\hline 6. & Brunai Darussalam & 7.567 \\
\hline 7. & Korea Selatan & 3.646 \\
\hline 8. & United Arab Emirat & 2.430 \\
\hline 9. & Qatar & 1.233 \\
\hline 10. & Oman & 928 \\
\hline 11. & Kuwait & 901 \\
\hline 12. & Italy & 831 \\
\hline 13. & Turkey & 492 \\
\hline 14. & New Zealand & 285 \\
\hline 15. & United States & 238 \\
\hline 16. & Zambia & 154 \\
\hline 17. & Maldives & 135 \\
\hline 18. & Bahrain & 119 \\
\hline 19. & Spain & 115 \\
\hline 20. & Aljazair & 109 \\
\hline 21. & Brazil & 109 \\
\hline 22. & Denmark & 109 \\
\hline 23. & Germany & 107 \\
\hline 24. & India & 92 \\
\hline 25. & China & 6411 \\
\hline 26. & Negara lainnya & \\
\hline & A m o u n t & 900 \\
\hline & P PSL & \\
\hline
\end{tabular}

\section{Resource : PUSLITFO BNP2TKI in year of 2016}

According to the table 1, it is known that the amount of Indonesia worker abroad in the year of 2016 (until November 2016) reached 212.900 people, spread across Asia, Middle East, USA, Europe, Pacific and Africa. The existence of Indonesian worker abroad certainly not apart from the problem that they faces abroad, namely : 
Table 2. The problem of Indonesian workers faces abroad

\begin{tabular}{|c|c|}
\hline No. & Problems \\
\hline 1. & $\begin{array}{l}\text { migration } \\
-\quad \text { illegal entry } \\
-\quad \text { overstayers } \\
-\quad \text { citizenship status }\end{array}$ \\
\hline 2. & $\begin{array}{l}\text { employment } \\
\text { - } \quad \text { unpaid salary } \\
\text { - } \quad \text { work accident } \\
\text { - } \quad \text { torture/physical abuse } \\
\text { - } \quad \text { sexual harassment } \\
\text { - inappropriate workload } \\
\text { - inappropriate working hours } \\
\text { - } \quad \text { can't stand to stay } \\
\text { - } \quad \text { misunderstanding }\end{array}$ \\
\hline 3. & $\begin{array}{l}\text { law } \\
\text { - civil law problems ( agreement, property } \\
\text { rights, marriage/divorce, inheritance, children } \\
\text { adoption etc). } \\
\text { - criminal problems whether as a defendan or } \\
\text { as a victim (drugs, murder, theft, torture, } \\
\text { raped etc). }\end{array}$ \\
\hline 4, & $\begin{array}{l}\text { others } \\
\text { - } \text { pass away } \\
\text { - } \text { severe illness/accident }\end{array}$ \\
\hline
\end{tabular}




\begin{tabular}{|l|l|}
\hline & repatriation.evacuation in terms of natural \\
& disasters or emergency situations etc \\
- & lost contact \\
& displaced
\end{tabular}

In the table 2, it is known that the problem which indonesian worker faces abroad including an immigration problem, employment, law etc.

The law problems which is indonesian worker faces abroad, can be divided into two, that are the problem that is brought up from resource country (Indonesia) and when they works abroad, the problem from resource country are:

a. The immigration document and the conditions for being indonesian worker which is not fulfilled when they will depart.

b. On the quarantee waiting for the departure abroad, there is a time when some of the indonesian worker faces a problem that harmed Indonesian worker, the delayed of their departure because of waiting for visa, a poor shelter, even the problem of sexual harassment particularly for the women workers.

c. Linked with the implementation of regulations, ranging from underage recruitment, false self document, low education and other technical matters.

The problem that encountered by Indonesian workers abroad:

a. Legal problem between Indonesian worker and the employer or between Indonesian worker and a country resident where they working, such as persecution by the employer, the violation of their rights, as well as criminal act which is did by an Indonesian worker themselves in the country where they working.

b. Clutter in sending Indonesia worker which is derived by the government officials who practicescorruption,collusion, nepotism in the field of sending Indonesia worker, the officials of PJTKI (agency of Indonesian worker services) who is less responsibility about the development and safety of Indonesian worker and more concerned only the advantages, there are officials abroad (Malaysia) who is protecting in recruitment of illegal Indonesia worker with a reason that the salary of illegal Indonesia worker is cheaper, easily frightened and squeezed. If there is an Indonesia worker who is not obedient then they will be reported to the police of the state. 
Volume 1, Issue 2, October 2017

c. The arbitrariness of the employer often experienced by indonesian worker such as mistreatment, sexual harassment even up to the murderer.

One of the republic of indonesia purposes as listed on the opening of 1945 constitution is to protect all citizens, including indonesian citizen who is working abroad. The definition of protection according to act No. 39 of 2004 on placement and protection for indonesian worker abroad is every effort to protect the interest of indonesia worker candidate in realizing the assurement of their rights satisfaction in accordance with the regulation, whether before, during, or after employment. The placement and protection for indonesian worker candidate is based on the alignment, equality of rights, democration, social justice, equality and gender justice, non discrimation along with anti humantrafficking.

The purposes of protection for indonesia worker as regulated under article 3 of act No 39 year 2004 are:

a. Empowering and utilizing labor optimally and humanly

b. Ensuring and protecting indonesian worker candidate since in domestic, the destination state, until they are back to the resource country of Indonesia.

c. Improving the development of Indonesia worker and their family

The placement and protection for indonesian worker abroad, government has a duty to arrange, develop, implement and oversee the enforcement of placement and protection for indonesian worker abroad, where in carrying out those duties the government able to delegates some of his authority and/or his duty assitance to the regional head in accordance with the law regulation. This matter means as a government responsibility to developed an effort to protect Indonesian workers abroad.

According to the discussion above it can be analyzed the weakness of law protection for indonesian worker regulation who work abroad by virtue of act No 39 year 2004, as listed below:

a. The provision which contained prohibition or obligation, but is not followed by threat of legal sanctions. It is existed in article 20 paragraph 1 which required PPTKIS to have an agency in the state where Indonesian worker is placed. This section should be completed with criminal sanction since it is contained norm obligation. This section means to developed Indonesian worker placement system abroad which shows the protection for worker as well as to prevent a placement of Indonesia worker illegally. Without law sanction particularly criminal sanction for the offender, then this regulation basically is 
not a law norm, except only as a social norm. basically, PPTKIS agency is a spearhead of PPTKIS abroad in action to placed Indonesia worker appropriately as well able to monitoring Indonesian worker who is placed well. The existence of agency abroad which acted for and in behalf of PPTKIS, then the placement of Indonesian worker abroad really is done with noticing Indonesian worker position as a human being along with their prestige and dignity, not as an export commodity. ${ }^{11}$

b. Unclear provision about who is the law subject which is subject to law liability. Article 27 paragraph 1 stated..."placing Indonesian worker abroad is only done to the country where its government have make a written agreement with Indonesian government or to the country that establish law regulation which concerning the protection of foreign workers". This provision does not giving a clear explanation who is the law subject, whether the government or the agency (PPTKIS) so reviewed from legal drafting aspect this matter is a law postulate which should be regulated under law norm. furthermore, it cannot formulated its law sanction because unclear law subject is to be charged.

c. Article 29 paragraph 1 specifying that "placement of Indonesian worker candidate is directed to the right position based on their expertise, skill, talent, interest and ability". This section formulation does not provide clarity who is the law subject. Therefore, this matter basicly as a law postulate that must be concreted in the law norm, so that able to be formulated its law sanction as well as the subject who is exposed his law obligation. A provision that should be formulated in form of "requirement" but is formulated in form of “optional".

d. Article 29 paragraph 1 of act Number 39 year 2004 stipulated that "private agency PPTKIS might forming a branch office in the region outside domicile of its office centre". From the function and its role view, the branch office PPTKIS in the recruitment region is occupy the strategic position in the recruitment process and candidate election of indonesian worker who is going to work abroad, therefore the "optional" form in this section should be in the form of "requirement", so that indonesian worker election from a recruitment region might be done right also able to avoid human exploitation/human trafficking.

11 Aloysius Uwiyono, (2015), Aspek Yuridis Penempatan Tenaga Kerja Indonesia di Luar Negeri, Makalah Disampaikanpada Seminar "Penempatan dan Perlindungan TKI di Luar Negeri" yang diselenggarakan oleh BPHN Depkum HAM, Surabaya, p. 3. 
Volume 1, Issue 2, October 2017

e. A norm which govern law subject who are outside borderline of Republic of Indonesia. Article 24 paragraph 2 stipulated " a business partner as mentioned in paragraph 1 must be a legal entity which is established based on the law regulation in the destination country". This typical provision is not exact and cannot be justified because its law subject as regulated under Indonesia provision is existed outside Indonesia borderline. They cannot be forced to obey the provision of Indonesia's law.

f. The existence of conflicting provision with each other (inconsistention). Article 4 specified " every individual is prohibited to placed Indonesian citizen to working abroad". This provision is not in line with article 30 which stated that "everybody is prohibited from placing Indonesian worker candidate in a position and a place of work which contradicted with the values of humanity and social norm nor law regulation, whether in Indonesia or in the destination country which is declared closed as mentioned in the article 27 '.

g. Article 7 letter a stated that one of the government duty is to guarantee the rights of indonesian workers candidate whether they departed through the placement commission of Indonesia worker nor who departed by their own. The candidate rights namely mentioned in article 8 that "to get the right information concerning labor market in oversea and the procedure of placement Indonesian worker abroad, gain the protection guarantee, safety, and a return safety of Indonesian worker to their origin. However in the article 34 paragraph 3 stated that the information concerning a placement and protection ofindonesian worker is delivered by PPTKIS, as well as the return of indonesian worker from receiving country until they arrived in the origin area is the responsibility of placement commissionofindonesian worker (Art 75 para 1).

h. Article 7e regulated about the government obligation to give protection for indonesian worker in terms before departure, placement period and end of placement period. However, under nextsections are not describe each scope of those protection. According to article 80 paragraph 1 which is only regulated protection for the placement period by giving legal aid in accordance with the regulation of destination country as well law and international custom, and advocacy to satisfy the rights according to the work contract and/or law regulation of placement country.

i. The existence of unilateral provision that govern law subject. Article 55 stated that " every Indonesian worker is required to signed a working agreement before the one who concerned is departed abroad. The signature of work agreement is done in front of the 
responsibility official in field of workforce. The work agreement meant to be prepared by the commission of private indonesian worker placement". This provision is not guarantee the legal certainty because the agreement is made based on the deal between worker/labor (indonesian worker candidate) with the employer/user of services. The work agreement which is signed by the indonesian worker candidate before departed abroad in front of the responsible officials in field of workforce is juridically arise a problem since the parties does not meet in person to declared the deal of those working agreement object that is offered by the employee/service users. Consequently, if the agreement which is signed by the worker candidate in their region of origin is not obey by the employee/service users, then the indonesian worker is difficult to do a legal charges because the employee might quibble they never make such worker agreement with the worker party.

\section{Norm Formulation of protection for indonesian worker which able to give direct protection}

On September 29 of 2004, Indonesian government has established act no 39 year 2004 concerning the placement and protection for indonesian worker abroad, LNRI (statute book of republic Indonesia) year 2004 number 113, TLNRI number 4445, in purpose to protect indonesian worker who working abroad. The protest from various parties is colouring the establishment of the act, such as : the services company of indonesian worker and various non-governmental organization which stand for indonesian migrant labor. The nongovernmental organization asses that the minimum public participation on discussion while darfting the act is become the main reason ever since to reject the ratification. Moreover, the house of representative is never announced to the migrant labor union. There are sections which is still controversial and is not give protection for indonesian worker who working abroad. Migrant worker activist asses that the content of the act is strongly defending the interest of PJTKI (the suplliers of indonesian employment services and is not at all provide the protection for indonesian worker whether from its pre placement stage, on the placement and after the placement. Indonesian worker also burdened with various charges of placement abroad.

According to Irmawati ${ }^{12}$ the selfsolidarity for migrant worker asses that the act of protection for migrant labor which resulted by the parliament and government are strengthen the state role, while the labor position is more like a merchandise which is sale to get foreign exchange as much as possible. The act of placement and protection for indonesian worker

12 Irmawati, "Puluhan Massa Demo Tolak RUU Buruh Migran", Tempo 27 September 2004. 
Volume 1, Issue 2, October 2017

abroad is no different with labor act which established in 2003, " only as the legal tools that adopted free market principle, while the state role to protect the poor are reduced, even eliminated. Rejection attitude also done by the PJTKI (company of indonesia worker services), mainly about the criminal sanctions which is considered too heavy. As well as the condition for being the agent services for indonesia worker placement abroad, must be incorporated and has a capital deposit of Rp. 3 billion plus deposit as warranty Rp. 500 million. With this amount of money, only the nonnative services company is able to become the placement commission of indonesian worker. ${ }^{13}$

Depart from the juridical analysis above concerning placement and protection for indonesian worker abroad it can be describe that the subtances of this act is not much different with previous provisions which is (Kepmenakertrans RI) the ministerial decree on labor and immigration number 140 A year 2002 concerning placement of indonesian worker abroad. This act doesnot provide the placement system of indonesian worker which take side for protection to the indonesia worker, this matter is reflected from things as follows:

1) The recruitment of indonesian worker is given to the company of agent services PPTKIS, even is still able to recruited indonesian worker from brokers, because there is no requirement for the company PPTKIS to form the agency in the recruitment region.

2) Training organizer is given to the PPTKIS. This matter surely arise a control problem which in general is very weak.

3) There are unclear provisions which is not clear its legal subject, but there is the criminal sanctions.

4) There are provisions which formulated in the "optional" form however is threatened with criminal sanctions.

5) On the contrary, there are provisions which is formed in the "requirement" form or orders and restriction however is not listing law sanctions.

6) There are provisions which govern foreign law subject which is out of indonesia borderline.

7) The provisions which regulated the law subject unilaterally particularly in form of work agreement.

8) Contained vague norm, even void norm

13 See more on Nakertrans magazine in $5^{\text {th }}$ edition TH.XXIV-December 2004, http://www.nakertrans.go.id/newsdetail.php?id=194, accessed: 18 September 2007. 
Low quality of subtantion in the act number 39 year 2004 concerning placement and protection for indonesian worker abroad as describe above is cannot released from domestic legal politic which behind it. The policy direction of domestic law development at that time is set in the GBHN (Broad outline of the state policy) 1999-2004 which stated that " domestic law system is lay out through the renewal of provisions of colonial heritage and domestic law that is dicriminative, including gender inequality and is not accordance with the reform expectation through the legislation program". The expalantion of those provisions is listed under act number 25 year 2000 concerning domestic development program in 2000-2004, one of the program is to form the regulation. This program purpose is to support the effort in terms to realizing the rule of law mainly improvement of the provisions that inherritance by the colonial and domestic law which is not suitable with the development of the people.

One of the law draft which become the priority at that time was the legal draft of workforce which is submitted by the government in the first of februari 2002. The discussion of this draft is classified tough because the strong line of rejection which came from the worker/labor union and enterpreneur. The labor asses that this legal draft is have not provide the law protection of the labor rights particularly involved the deal of particular working time and the passes of outsourcing, while the enterpreneur asses that various subtantions is burdensome for example concerning work termination particularly to pay severance, and the wage at the strike time. However, according to the discussion by the representatives and givernment which including also the enterpreneur and labor organisation, various problems which blocked in the legal draft was reached the deal and finally in the february 2003 the legal draft is passed by the house of representative and was establish in the mei 25 of 2003 turn out to act number 13 year 2003 concerning workforce. This act lifted various ordonant which inherit by the colonial, one of the is the ordonant concerning the mobilization of indonesian to do the labor outside indonesia (staatsblad year 1887 number 8 )) in the section 34 which mandated provision about placement of the worker abroad is regulated under the act.

According to the mandate of labour law, the government have prepared the legal draft of palcement and protection for indonesia worker and started to be discussed in the parliament since fbruary 2004, which is same as the time when discussion of labour act. The legal draft concerning placmenet and protection for indonesia worker is loaded with protest from nongovernment organisation which stand for the migrant labor. Their veiw is this legal draft 
Volume 1, Issue 2, October 2017

is as the main justification for the government to send indoesia worker abroad as much as possible without considering the protection aspect. However the government party is continue to tried so that those legal draft is passed and establish as the act before the regime of megawatia s president and the heouse representative was end with the reason that legal needs concern the protection tools is urgently because until today the placement of indonesia worker abroad is only done through the legislation form and or the labour minister decision. Finally, thorugh the plenary meeting of indonesia house of representative in the 29 sept 2004 the legal draft was passed and turn to act and at 28 october 2004 is establish as act no 39 number 2004 concerning palcement and protection for indonesia worker abroad. State gazette of republic indonesia year 2004 number 133, supplement state gazette of repubic indonesia Number 445 .

Similiarly as the act Number 13 of 2003 on labour laws, this act number 39 of 2004 is also not based on the academic draft, most of it subtances is taken from the previous regulation which is the ministrial decree on labour and transmigration laws number $140 \mathrm{~A}$ year 2002 concerning the placement indonesian worker abroad. Therefore it is not surprisingly if the subtances of this act is more nuanced as placemenet than as a protection.

When the govenrment prepared for the act draft on palcement and protection for indonesian worker actually there is an act draft which is prepared by consortium for the defense of indonesian migrant workers in cooperation with law faculty of brawijaya university Malang which its subtances is more emphasizing on the protection for indonesian workers, however the government does not welcome to use the draft of the act. Judging from the perpective of legal politic this matter can be understood because the government have had its own legal policy which will be established. According to Bagir Manan " the law politic at least covering three aspect which is political establishment of law, politic about the subtances of (principles and rule of law, and politics of law enforcement). ${ }^{14}$ Therefore which field of law that get the priority from the government to be formed, as well as its subtances have been prepared before which is suitable with the plan that has been established.

In quantity recognized that the parliement of 1999-2004 was resulted the most regulation in history of the house of representative of indonesia which is reached 172 manuscript during their services. The amount of the act that reach the highest in the history, which exceed the amount of the act that is reached by the central indonesian national

\footnotetext{
14 Bagir Manan on Latief Fariqun, (2007), “ Pengakuan Hak Masyarakat Hukum Adat Atas Sumber Daya Alam dalam Politik Hukum Nasional”, Disertasi, Program Doktor Ilmu Hukum Fakultas Hukum Universitas Brawijaya Malang, p. 62.
} 
committe as many as 135 manuscrpit of act. ${ }^{15}$ Other than that as the member of people's consultative assembly, the people representative council of this period also succed to ammend the 1945 constitution for four times that is at 1999 (firstly), 2000 (secondly), 2001 (at the third) and 2002 (fourth). However, in quality have not satisfiying yet, this can be seen from the number generated act which requested to be examine in the constitutional court, the number of the act being replaced after enacted.

The formulation of norms on protection for indonesian workers which give decent protection, dignified and justified, should pay attention:

a) Perform a legal reform on the act number 39 of 2004 concerning the placement and protection for indonesian worker abroad by reviewing the principles that is less relevant and included the humanity principle and state responsibility principle as its bottom footing. Its principle divided in the norm which regulated the roghts and obligation of the parties ( government, PPTKIS and TKI) consistently obeyed the principle as well as the placemet system which oriented in the protectin. The reform performed with making an academic draft which perform by indlucing participation of the stakeholders.

b) Pre palcement institutions and protection for indonesian workers in the region level is performed by the particular institution, such as : the region agency of palcement and protection for indnesian worker as the recruitment agency, selection and protection for the candidate of indonesian worker. In the central level by perfroming the central institution of placement and protection for indonesian worker which working as the agency of placement and protection at the time of placement and coordinated with the region level in repatriation or full placement of indonesian workers.

c) Giving wider authority to the local government concerning protection for pre palcement particularly on providing information to the candidate of workers about labour markert abroad and work training so the region can be more freely in role and form the regulation concerning this matter in accordance with its character and what its citizens need.

\footnotetext{
15"DPR 1999-2004 Pecahkan Rekor Pencetak UU Terbanyak", dalam http://fh-unpad. blogspot. com/2004/09/dpr-1999-2004-pecahkan-rekor-pencetak.html, accessed : 2 September 2009.
} 


\section{CONCLUSION}

The weakness of the act number 39 of 2004 on placement and protection for indonesian worker so its not provide decent protection, this is due to the provision which contain "prohibition or obligation, however it is not followed by the legal sanctions. The existence of norm which is not provide clarity in who is the law subject, whether it is te government or PPTKIS. The existence of "optional" norm which should formed in "obligation", so that the selection of indonesian worker from the recruitment region is performed appropriately also to prevent from human explotation/human trafficking. The existence of norm which regulaated the law subject which is outside the boundaries of the territory of unitary state of the republic indonesia. Some provision which regulatedd law subject unilaterally. There is no law certainty because the work agremeent is made based on the deal between the workers/labor (worker candidate) with the employer/service user which juridically created the problem because the parties did not meet in person to stated their agreement of the contents of the employment agreement which is offered by the employer/service user. Consequently, if the employment agreement has been signed by the candidate party of indonesian worker in the region of origin is not obeyed by the employer/service user then the indonesian workers is difficult to perform lawsuits.

The norm formulation of protection for indonesian worker which provide decent protection.

By listing the humanity principle and state responsibility as its bottom footing. This principle is describe in the norm which regulated the rights and obligation of the parties (governmnet, PPTKIS and TKI) consistenly obey the principle as well as the placement system which oriented on the protection. The reformation is formed by preparing an acdemic draft which is formed by including the participation of the stakeholders.

\section{Bibliography}

\section{Books and Journal}

Aloysius Uwiyono, (2015), Aspek Yuridis Penempatan Tenaga Kerja Indonesia di Luar Negeri, Makalah Disampaikan pada Seminar "Penempatan dan Perlindungan TKI di Luar Negeri” yang diselenggarakan oleh BPHN Depkum HAM, Surabaya.

Bagir Manan on Latief Fariqun, (2007), “ Pengakuan Hak Masyarakat Hukum Adat Atas Sumber Daya Alam dalam Politik Hukum Nasional", Disertasi, Program Doktor Ilmu Hukum Fakultas Hukum Universitas Brawijaya Malang. 
Bernard Arief Sidharta, (2000), Refleksi Tentang Struktur Ilmu Hukum Sebuah Penelitian tentang Fundasi Kefilsafatan dan Sifat Keilmuan Ilmu Hukum sebagai Landasan Pengembangan Ilmu Hukum Nasional, Bandung : Mandar Maju.

Irmawati, "Puluhan Massa Demo Tolak RUU Buruh Migran", Tempo 27 September 2004.

Lalu Husni, Prof.Dr.,SH,M.Hum, (2015), Hukum Penempatan Dan Perlindungan TKI (edisi revisi), Program Pascasarjana Universitas Brawijaya Malang.

Soetandyo Wignjosoebroto,(1995), "Sebuah Pengantar Ke Arah Perbincangan Tentang Pembinaan Penelitian HukumDalam PJP II": Jakarta : BPHN Departemen Kehakiman.

Tajudin Noer Efendi Editor M.Arief Nasutioni, (1999), Peluang Kerja dan Antisipasi Menghadapi Era Pasar Bebas, Bandung : Alumni.

\section{World Wide Web}

"DPR 1999-2004 Pecahkan Rekor Pencetak UU Terbanyak", dalam http://h-unpad. blogspot. com/2004/09/dpr-1999-2004-pecahkan-rekor-pencetak.html, accessed : 2 September 2009.

Nakertrans magazine in $5^{\text {th }}$ edition TH.XXIV-December 2004, http://www.nakertrans.go.id/newsdetail.php?id=194, accessed: 18 September 2007.

Tribunnews. Com, tanggal 23 November $2010: 1$

http://www.bnp2tki.go.id/uploads/data/data_09-12-

\section{6_122020_Laporan_Pengolahan_Data_BNP2TKI_S.D_November_2016_.pdf}

Act

Undang-Undang Republik Indonesia Nomor 30 Tahun 2004 Tentang Jabatan Notaris (Lembaran Negara Republik Indonesia Tahun 2004 Nomor117,Tambahan Lembaran Negara Republik Indonesia Nomor 4432);

Undang-Undang Republik Indonesia Nomor 2 Tahun 2014 TentangPerubahanAtasUndangUndangNomor 30 Tahun 2004 TentangJabatanNotaris, (Lembaran Negara Republic Indonesia Tahu 2014 Nomor 3, TambahanLembaran Negara Republik Indonesia Nomor 5491);

Undang-Undang Republik Indonesia Nomor 30 Tahun 2014 Tentang Administrasi Pemerintahan, (Lembaran Negara Republik Indonesia Tahun 2014 Nomor 292, Tambahan Lembaran Negara Republik Indonesia Nomor 5601);

Peraturan Menteri Hukum Dan Hak Asasi Manusia Republik Indonesia Nomor 7 Tahun 2016 
Tentang Majelis Kehormatan Notaris;

Peraturan Menteri Hukum Dan Hak Asasi Manusia Republik Indonesia Nomor 25 Tahun 2014 TentangSyarat Dan Tata Cara Pengangkatan, Perpindahan, Pemberhentian, Dan Perpanjangan Masa Jabatan Notaris;

Peraturan Menteri Hukum Dan HakAsasi Manusia Republik Indonesia Nomor 27 Tahun 2016 Tentang Formasi Jabatan Notaris Dan Penentuan Kategori Daerah; 